\title{
Regulation of gastric function by endogenous gastrin releasing peptide in humans: studies with a specific gastrin releasing peptide receptor antagonist
}

P Hildebrand, F S Lehmann, S Ketterer, A D Christ, T Stingelin, J Beltinger, A H Gibbons, D H Coy, J Calam, F Larsen, C Beglinger

\begin{abstract}
Background and aims-The main goal of our study was to characterise the activity of BIM26226 as a peripheral gastrin releasing peptide (GRP) receptor antagonist in healthy human subjects and to determine if endogenous GRP is a physiological regulator of gastric acid secretion and gastrin release.

Methods-Our study consisted of three parts. In part I, subjects received saline or BIM26226 followed by graded doses of intravenous human GRP in a four period crossover design. In part II, subjects received BIM26226 or saline during oral meal ingestion or modified sham feeding. In part III, subjects received an acidified meal in the presence and absence of BIM26226 in a two period crossover design. In addition, gastrin and somatostatin mRNA were measured in biopsy specimens during saline and BIM26226 infusion.
\end{abstract}

Results-BIM26226 dose dependently inhibited GRP induced acid output. Acid secretion after oral liquid meal intake and sham feeding was significantly inhibited by BIM26226 $(\mathrm{p}<0.01)$ whereas plasma gastrin release remained unchanged. Gastrin and somatostatin mRNAs were not significantly different after saline or BIM26226.

Conclusions-BIM26226 is a potent GRP antagonist in humans. Endogenous GRP may be a physiological regulator of gastric acid secretion. Gastrin release does not seem to be under the control of GRP. (Gut 2001;49:23-28)

Keywords: gastrin; gastric acid secretion; gastrin releasing peptide; gastric function; BIM26226

Ipsen Internationa Ltd, London W8 5HH, UK

F Larsen

Division of Medicine, Medicine A, Hammersmith Hospital, London W12 0NN, UK A H Gibbons

J Calam

Correspondence to: Professor C Beglinger. beglinger@tuir.ch

Accepted for publication 20 December 2000 at the same time. ${ }^{34}$ Current data indicate that stimulation of acid secretion predominantly occurs in a paracrine/neurocrine manner (histamine, acetylcholine) whereas the stimulating effect mediated by gastrin may be less important. $^{5}$

In humans, gastrin releasing peptide (GRP) seems to stimulate acid secretion by release of gastrin. ${ }^{6}{ }^{7}$ Studies measuring the effect of intravenous GRP infusion have demonstrated that low, so called physiological, concentrations of GRP stimulate gastrin release and acid secretion in healthy volunteers. However, the physiological relevance of these observations is limited by the fact that GRP is a neuropeptide and not a circulating hormone. To date, it has not been possible in humans to selectively inhibit GRP release from nerve terminals or to block the action of GRP by inhibiting its binding in target tissues.

Recently, [D-F $\left.-\mathrm{Phe}^{6}, \mathrm{D}-\mathrm{Ala}^{11}\right] \mathrm{Bn}(6-13) \mathrm{OMe}$ (BIM26226) has been developed which is specific for GRP preferring bombesin receptors. ${ }^{8}$ In rat pancreatic acini as well as in the rat pancreatic carcinoma cell line AR4-2J, BIM26226 had the same binding affinity as bombesin and GRP but at least 300-fold lower affinity for neuromedin $\mathrm{B}(\mathrm{NMB})$ preferring bombesin receptors. ${ }^{9}$ BIM26226 potently inhibited bombesin stimulated amylase release from both rat pancreatic acini and AR4-2J cells. Intravenous bolus injection inhibited bombesin stimulated amylase release for up to 4.5 hours, ${ }^{10}$ suggesting that in animals, BIM26226 is a potent and specific GRP antagonist in vitro and in vivo.

The present investigation comprised three parts (I-III). In part I, subjects received saline (control) or one of three intravenous doses of BIM26226 followed by graded doses of intravenous human GRP in a four period crossover design. The objectives of this part of the study were to demonstrate that intravenous BIM26226 is an effective GRP receptor antagonist in humans and to establish the dose range of antagonist activity based on inhibition of GRP stimulated acid secretion and hormone release. In part II, subjects received a continuous infusion of BIM26226 or saline (control) followed by oral ingestion of a meal or modified

Abbreviations used in this paper: GRP, gastrin releasing peptide; PEG, polyethylene glycol; CCK, cholecystokinin; GAPDH, glyceraldehyde phosphate dehydrogenase; NMB, neuromedin B; ECL, enterochromaffin-like. 
sham feeding. The aim of this part of the study was to assess the physiological role of endogenous GRP on meal induced intragastric acidity, sham feeding stimulated acid output, and meal stimulated plasma gastrin response. In part III, subjects received an acidified meal in the presence and absence of BIM26226 in a two period crossover design. The objective was to investigate plasma gastrin release under GRP receptor blockade at controlled intragastric $\mathrm{pH}$.

\section{Methods}

EXPERIMENTAL SUBJECTS

Thirty healthy male subjects, 20-48 years of age, participated in the studies. Each subject gave written informed consent and had a normal physical examination and laboratory tests. All subjects were Helicobacter pylori negative $\left({ }^{13} \mathrm{C}\right.$ urea breath test). The study was approved by the ethics committee of the University Hospital of Basel.

BIM26226

BIM26226 was synthesised by DH Coy at Tulane University, New Orleans, Louisiana, USA (chemical purity $>97 \%$ ) and provided as lyophilised powder by Biomeasure Inc. (Milford, Massachusetts, USA). In addition to GRP/NMB receptors, BIM26226 has been examined for its in vitro binding to a total of 26 different receptors, among them cholecystoki-

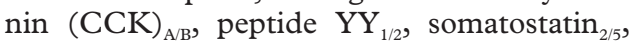
histamine $_{2}$, PACAP $_{1 / 2}$, secretin, and vasoactive intestinal peptide. Specificity of binding was demonstrated by Ki values $>1000 \mathrm{nM}$ for all non-bombesin receptors tested (John Taylor, personal communication). Plasma concentrations of BIM26226 at an infusion rate of 500 $\mu \mathrm{g} / \mathrm{kg} / \mathrm{h}$ were in the range $200-400 \mathrm{nmol} / 1$ whereas doses of 50 and $5 \mu \mathrm{g} / \mathrm{kg} / \mathrm{h}$ induced 10and 100-fold lower concentrations. Fifteen minutes after the end of infusion, the compound was not detectable, indicating a plasma half life of less than two minutes. Based on plasma concentrations induced by the highest dose of BIM26226, it can be estimated that the ratio of agonist/antagonist at the receptor site is in the range 1:1000, which is necessary to inhibit function by more than $97 \% .^{11}$

\section{STUDY PROTOCOLS}

Each experiment was performed on a different day and in random order. Subjects were fasted overnight before each experiment.

\section{Effect of BIM26226 on GRP stimulated acid output}

Eight subjects participated in a four period, double blind, placebo controlled, crossover study. On each experimental day subjects swallowed a double lumen gastric tube which was positioned under fluoroscopic control. On four days, separated by at least three days, volunteers received intravenous infusions of saline (control) or one dose of BIM26226 (5, 50, or $500 \mu \mathrm{g} / \mathrm{kg} / \mathrm{h}$ ). After a baseline period of 60 minutes, increasing doses of synthetic human GRP $(10,30$, and $90 \mathrm{pmol} / \mathrm{kg} / \mathrm{h}$; Novabiochem, CH-4448 Läufelfingen, Switzerland) were given intravenously, each dose for 45 minutes. Continuous intragastric perfusion of a non-absorbable marker, polyethylene glycol (PEG4000), was administered throughout the study at a rate of $3 \mathrm{ml} / \mathrm{min}$ to correct for duodenal loss. Gastric acid secretion was collected continuously in 15 minute aliquots. Blood was drawn at various time points for determination of plasma gastrin.

Effect of BIM26226 on meal stimulated intragastric acidity and plasma gastrin release In 10 subjects intragastric acidity was measured by miniature combined glass electrodes (Ingold Lot 440; CH-8902 Urdorf, Switzerland) placed in the gastric body and connected to a portable $\mathrm{pH}$ data logger (gastrograph Mark III; Medical Instruments Corp., CH-4500 Solothurn, Switzerland). The electrodes were calibrated at $20^{\circ} \mathrm{C}$ using commercial buffer solutions, and temperature correction for intragastric readings $\left(37^{\circ} \mathrm{C}\right)$ was performed. The electrodes were passed transnasally and positioned $8-10 \mathrm{~cm}$ below the lower oesophageal sphincter; the correct position was verified by fluoroscopy. Intragastric $\mathrm{pH}$ was measured every six seconds throughout the experiments. On two different days, subjects received intravenous infusions of either saline (control) or BIM26226 (500 $\mu \mathrm{g} / \mathrm{kg} / \mathrm{h}$ ) in a double blind crossover manner. After a baseline period of 120 minutes, each subject ingested a liquid $500 \mathrm{kcal}$ test meal (500 ml Ensure; Abbott, CH-6330 Cham, Switzerland) within 10 minutes while $\mathrm{pH}$ monitoring continued. After four hours, a second $500 \mathrm{kcal}$ Ensure meal was ingested and $\mathrm{pH}$ monitoring continued for another three hours. Blood was drawn at various time points for measurement of plasma gastrin.

\section{Effect of BIM26226 on modified sham feeding} stimulated acid output

In six subjects a double lumen gastric tube was inserted transnasally into the stomach on two different days. They received a meal consisting of sandwiches (cooked ham, white bread and butter) and $200 \mathrm{ml}$ of milk for modified sham feeding using the chew and spit technique. ${ }^{12}$

Volunteers were trained in advance not to swallow any food, liquid, or saliva. Recovered gastric juice was visually monitored and showed no evidence of accidentally swallowed food. Gastric acid secretion was continuously quantified in 15 minute aliquots as described above. PEG4000 was used as a non-absorbable marker to correct for duodenal loss. The experiments were performed with intravenous saline infusion (control) or with BIM26226 $(500 \mu \mathrm{g} / \mathrm{kg} / \mathrm{h})$ in a double blind crossover fashion. Saline or BIM26226 was started 60 minutes before modified sham feeding. Blood was drawn as described above.

Effect of BIM26226 on plasma gastrin at constant intragastric $p H$

Six subjects swallowed a $\mathrm{pH}$ electrode on two different days. After a two hour baseline period, an acidified liquid test meal (Ensure) was perfused into the stomach at a rate of $8 \mathrm{ml} / \mathrm{min}$ 
over 60 minutes. The meal was prepared by mixing $60 \mathrm{ml}$ of $1 \mathrm{M} \mathrm{HCl}$ thoroughly with 500 $\mathrm{ml}$ of Ensure, giving a $\mathrm{pH}$ of 2.3-2.5. The experiments were performed twice in each subject, once with intravenous saline infusion (control) and once with BIM26226 (500 $\mu \mathrm{g} / \mathrm{kg} / \mathrm{h}$ ) in a double blind crossover design. Blood was drawn at regular intervals for determination of plasma gastrin.

Effect of BIM26226 on gastrin and somatostatin $m R N A s$

Seven subjects received either intravenous saline or BIM26226 $(500 \mu \mathrm{g} / \mathrm{kg} / \mathrm{h})$ for three hours on separate days. At the end of the infusion, they underwent gastric endoscopy. $\mathrm{Mu}-$ cosal biopsies (four from the antrum and two from the corpus) were taken and immediately stored in liquid nitrogen until further analysis. Quantitative determination of gastrin and somatostatin mRNA compared with glyceraldehyde phosphate dehydrogenase (GAPDH) mRNA, extracted from gastric biopsies, was performed by northern blotting as described previously. ${ }^{13}$

\section{EXPERIMENTAL MEASUREMENTS}

Gastric acid secretion

The volume of all gastric aspirates was measured to the nearest $1 \mathrm{ml}$ and gastric juice was analysed for $\left[\mathrm{H}^{+}\right]$and [PEG4000]. Acid concentration was determined by the backtitration method and PEG4000 turbidimetrically. ${ }^{14}$ The marker perfused in the stomach served as a control parameter to calculate acid output for a given period. ${ }^{15}$ Results are expressed as the mean of the last two 15 minute periods during each dose. Data are presented as mean (SEM). Recovery rate was 86 (7)\%.

\section{Gastrin radioimmunoassay}

Plasma gastrin concentration was measured using a commercially available antiserum with negligible cross reactivity with CCK or other gastrointestinal peptides. The sensitivity of the assay was $25 \mathrm{pg} / \mathrm{ml}$. All samples from a single protocol were run in the same assay with an intra- and interassay variation of $<10 \%$ (Pantex, Santa Monica, USA).

\section{STATISTICAL ANALYSIS}

Data were calculated using an analysis of variance model for either a four or two period crossover design followed by a parametric or non-parametric test, as appropriate. ${ }^{16}$ Data were tested for normal distribution using the Komolgorov-Smirnov test and for homogeneity of variances according to Levine's test. ${ }^{16}$ Intragastric acidity readings were transferred from the portable registration unit to a computer and mean $\mathrm{pH}$ values for one minute intervals were calculated. From individual one minute $\mathrm{pH}$ values, medians for the fasting state and after meal intake were calculated. Group medians were compared using the Wilcoxon signed rank test. Gastrin results are expressed as mean (SEM). Integrated plasma hormone and gastric acid responses are expressed as area under the output curve, defined as the increase over basal values and calculated according to the trapezoid rule. ${ }^{16}$

\section{Results}

EFFECT OF BIM26226 ON GRP STIMULATED ACID OUTPUT AND PLASMA GASTRIN RELEASE

Subjects received intravenous infusions of saline (control) or one dose $(5,50$, or 500 $\mu \mathrm{g} / \mathrm{kg} / \mathrm{h}$ ) of BIM26226. After a baseline period of 60 minutes, graded doses of human synthetic GRP $(10,30$, and $90 \mathrm{pmol} / \mathrm{kg} / \mathrm{h})$ were administered, each dose given for 45 minutes. Basal acid output in the control experiments was $1.27(0.24) \mathrm{mmol} / 15$ minutes. The lower two doses of BIM26226 had no effect (1.35 (0.35) and $1.11(0.12) \mathrm{mmol} / 15$ minutes, respectively) whereas $500 \mu \mathrm{g} / \mathrm{kg} / \mathrm{h}$ significantly inhibited basal acid output (0.47 (0.06) $\mathrm{mmol} / 15$ minutes; $\mathrm{p}<0.05)$. Changes in acid output in response to graded GRP infusion and the ability of various doses of BIM26226 to affect this change are shown in fig $1 \mathrm{~A}$. In the saline (control) experiment, infusion of GRP promptly stimulated gastric acid secretion with a maximal secretory response obtained at 30 $\mathrm{pmol} / \mathrm{kg} / \mathrm{h}$. The highest dose of GRP (90 pmol/ $\mathrm{kg} / \mathrm{h}$ ) failed to further increase acid output although plasma gastrin values continued to rise (see below). In comparison with stimulation with pentagastrin, the response to exogenous GRP infusion was clearly submaximal.

BIM26226 dose dependently inhibited GRP induced acid output. Although $5 \mu \mathrm{g} / \mathrm{kg} / \mathrm{h}$
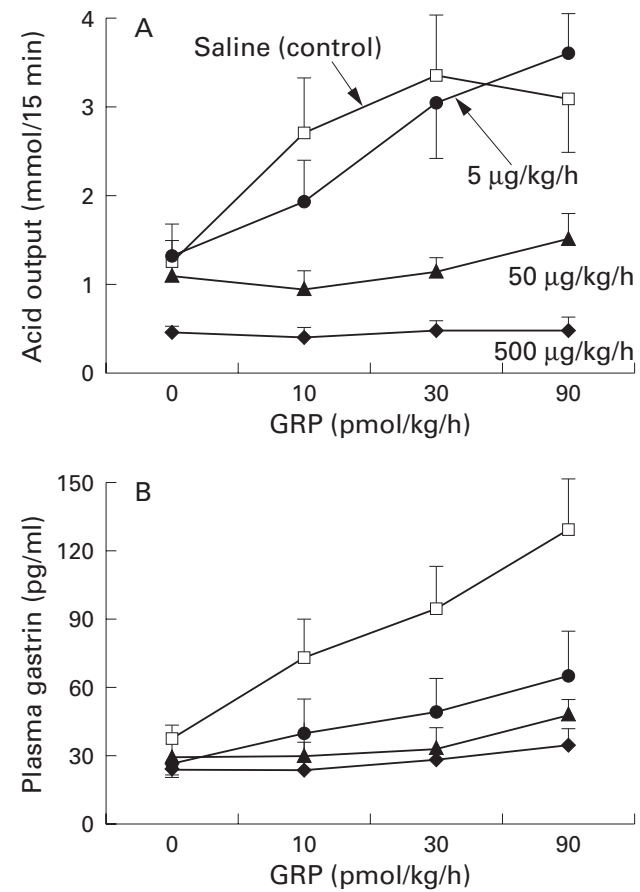

Figure 1 (A) Effect of saline or one dose of BIM26226 $(5,50,500 \mu \mathrm{g} / \mathrm{kg} / \mathrm{h})$ on gastric acid output during infusion of graded doses of synthetic human gastrin releasing peptide (GRP) $(0,10,30,90 \mathrm{pmol} / \mathrm{kg} / \mathrm{h})$. Acid output is presented as mmol/15 minutes and results are mean (SEM) of eight subjects. BIM26226 dose dependently inhibited integrated acid responses; a dose of $500 \mu \mathrm{g} / \mathrm{kg} / \mathrm{h}$ completely blocked basal and maximally GRP stimulated acid secretion $(p<0.01)$. (B) Plasma gastrin concentrations during the same study. Results are expressed as mean (SEM).

BIM26226 dose dependently inhibited integrated gastrin responses; $500 \mu \mathrm{g} / \mathrm{kg} / \mathrm{h}$ completely blocked GRP stimulated plasma gastrin release $(p<0.01)$. 
BIM26226 did not significantly modify the integrated response to GRP, the dose response curve was shifted to the right with the same maximal response. A dose of $50 \mu \mathrm{g} / \mathrm{kg} / \mathrm{h}$ significantly decreased the integrated acid response compared with control values $(\mathrm{p}<0.05)$, and $500 \mu \mathrm{g} / \mathrm{kg} / \mathrm{h}$ BIM26226 completely inhibited GRP stimulated acid secretion in the dose range tested $(\mathrm{p}<0.01 v$ placebo). Mean basal gastrin concentrations were not different between the four treatments. Graded doses of GRP induced increasing plasma gastrin concentrations in the saline (control) experiment which were dose dependently inhibited by increasing doses of BIM26226 (fig 1B).

\section{EFFECT OF BIM26226 ON MEAL STIMULATED} INTRAGASTRIC ACIDITY AND PLASMA GASTRIN Subjects received either intravenous saline (control) or BIM26226 (500 $\mu \mathrm{g} / \mathrm{kg} / \mathrm{h}$ ). The 11 hour $\mathrm{pH}$ profiles of both treatments (placebo or BIM26226) are shown in fig $2 \mathrm{~A}$. Median $\mathrm{pH}$ (interquartile range) in the pre-lunch period (0-2 hours) was 1.2 (range 1.0-1.5) with placebo. With BIM26226, median $\mathrm{pH}$ was 1.8 (range 1.5-2.0; $\mathrm{p}<0.05$ ). In the placebo (saline) experiments, intragastric acidity after both meals showed a similar pattern; $\mathrm{pH}$ increased to 4.5 and returned to basal values within three hours. In contrast, with BIM26226 postprandial $\mathrm{pH}$ was $4-6$ after the first meal and remained elevated during the whole interdigestive period. The second meal did not induce any further changes in $\mathrm{pH}$.
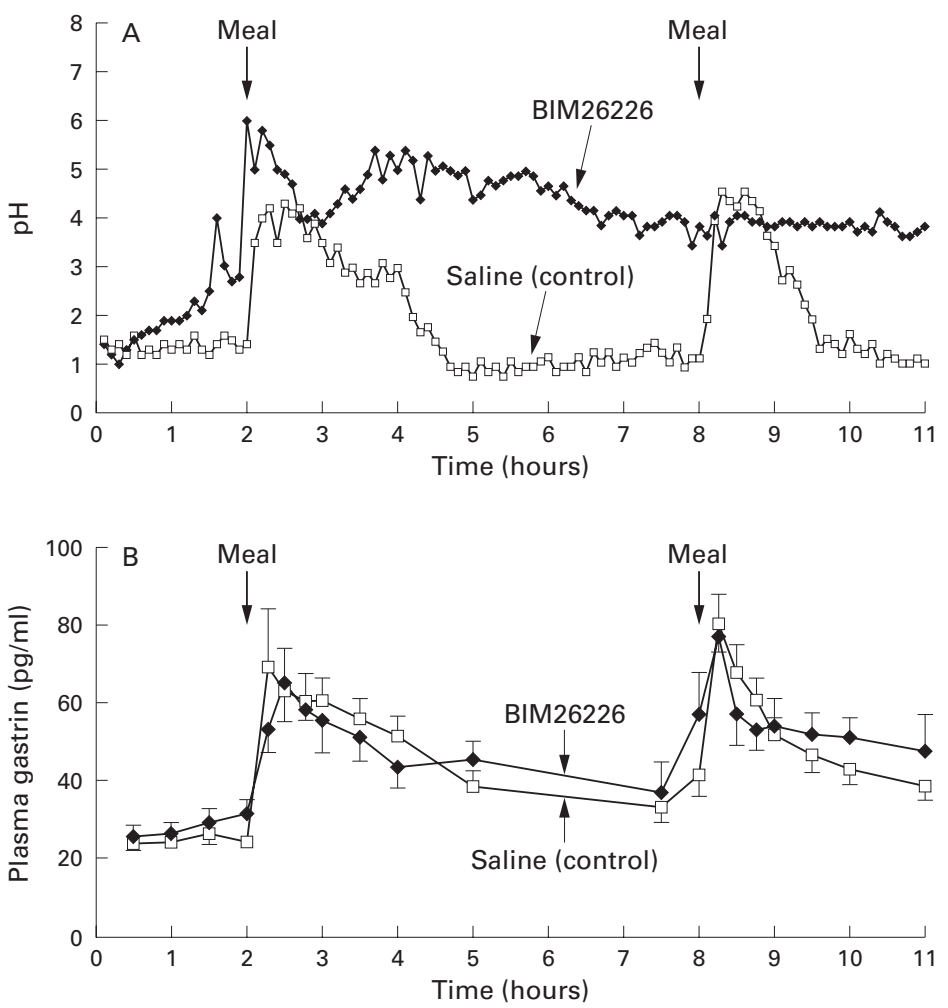

Figure 2 (A) Time course of intragastric acidity before and after oral ingestion of two liquid meals with and without concomitant infusion of BIM26226 $(500 \mu \mathrm{g} / \mathrm{kg} / \mathrm{h})$ in 10 healthy volunteers. Data are presented as medians. Intragastric acidity was significantly increased during infusion of BIM26226 $(p<0.01)$. (B) Plasma gastrin concentrations during the same study with and without BIM26226 $(500 \mu \mathrm{g} / \mathrm{kg} / \mathrm{h})$. Results are expressed as mean (SEM). Basal and postprandial plasma gastrin levels were not significantly different with and without BIM26226.
Total 11 hour intragastric $\mathrm{pH}$ was significantly higher with BIM26226 (4.1 (0.5)) compared with placebo $(1.4(0.4) ; \mathrm{p}<0.01)$. We cannot exclude the fact that the major effect of the antagonist was primarily on basal acid secretion; however, the study with cephalic stimulation of acid secretion favours the interpretation that BIM26226 inhibited basal and stimulated acid output (see below).

Plasma gastrin levels before and after meal intake are shown in fig 2B. Pre-lunch (0-2 hours) levels were not significantly different although values during BIM26226 were slightly higher. The first meal induced a rapid increase with a subsequent decrease during the postprandial period (2-5 hours). A similar pattern was seen after the second meal. BIM26226 did not suppress meal stimulated gastrin release.

Modified sham feeding resulted in a significant increase in acid output which was suppressed by intravenous BIM26226 (fig 3A). In the control study, plasma gastrin concentrations were increased in response to modified sham feeding but the difference compared with basal levels was not statistically significant. The lack of a significant increase in gastrin levels could have been caused by a type II error, as only a small number of subjects were tested. Plasma gastrin concentrations before and after sham feeding were not statistically different with and without BIM 26226 (fig 3B).
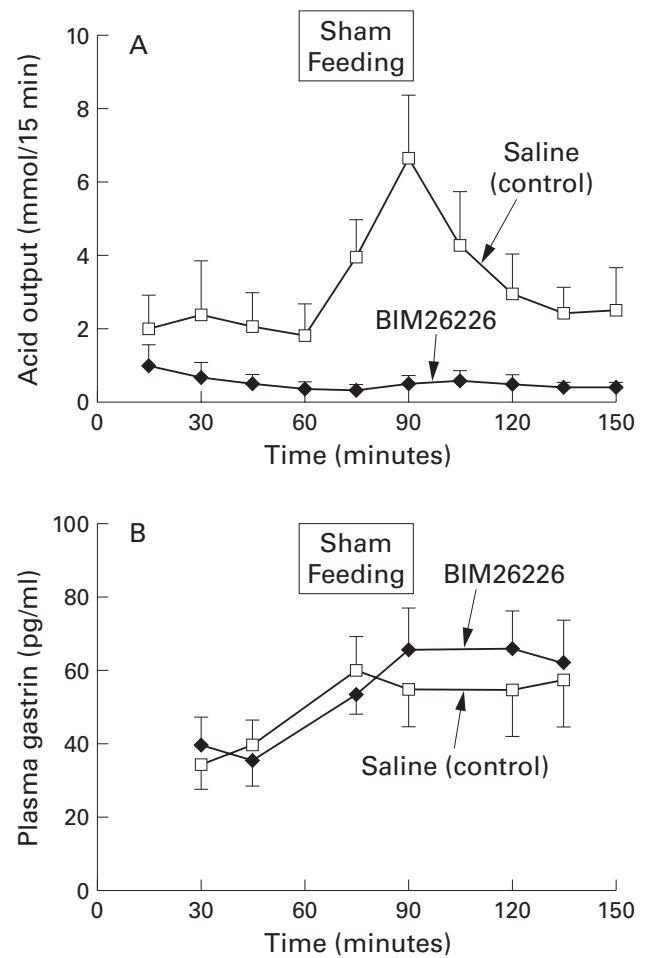

Figure 3 (A) Gastric acid output (mmol/15 minutes) in response to modified sham feeding with and without concomitant BIM26226 $(500 \mu \mathrm{g} / \mathrm{kg} / \mathrm{h})$ in six healthy subjects. Data are presented as mean (SEM). BIM26226 significantly suppressed acid output compared with control values $(p<0.05)$. (B) Plasma gastrin concentrations during the same study. Results are expressed as mean (SEM).

Plasma gastrin levels before and after sham feeding were not significantly different with and without BIM26226. 


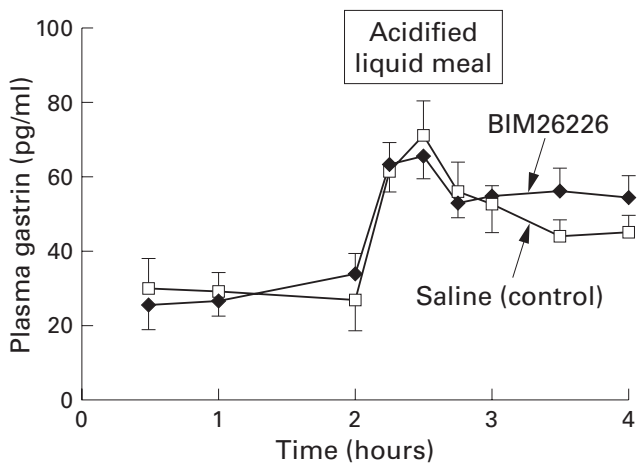

Figure 4 Plasma gastrin responses before, during, and after intragastric instillation of an acidified liquid meal with and without concomitant intravenous BIM26226 in six healthy subjects. Basal as well as meal stimulated gastrin release were not significantly changed by BIM26226.

EFFECT OF BIM26226 ON PLASMA GASTRIN AT CONSTANTLY LOW INTRAGASTRIC $\mathrm{pH}$ Perfusion of an acidified liquid test meal at $\mathrm{pH}$ 2.3 resulted in a steady intragastric $\mathrm{pH}$. In each single experiment, for both intravenous saline and BIM26226 infusion, median intragastric pH was below 2.3 (BIM26226 median pH 1.7 (range 1.4-2.2); saline median $\mathrm{pH} 1.3$ (range 1.0-1.7)). Perfusion of the meal into the stomach induced a significant increase in plasma gastrin $(\mathrm{p}<0.05)$ whereas BIM26226 did not affect this response (fig 4 ).

EFFECT OF BIM26226 ON GASTRIN AND

SOMATOSTATIN mRNA

Biopsy specimens taken at the end of three hours of saline or BIM26226 infusion were quantified for gastrin mRNA, somatostatin mRNA, and GAPDH mRNA by northern blot analysis. Results are expressed as a ratio of peptide mRNA to GAPDH mRNA (mean (SEM), n=7). Gastrin mRNA to GAPDH mRNA ratio in antral samples was not different with (1.66 (0.39)) or without (1.91 (0.37)) BIM26226. Ratios of somatostatin mRNA to GAPDH mRNA were not altered with or without BIM26226, either in the antrum (0.179 $(0.042) v 0.199(0.038))$ or the corpus $(0.094$ $(0.021) v 0.068(0.016))$.

ADVERSE EFFECTS

No adverse effects or significant changes in blood chemistry, urine, or electrocardiograms were observed after intravenous administration of BIM26226.

\section{Discussion}

In our study, we showed for the first time that BIM26226 is a potent GRP receptor antagonist in humans. BIM26226 inhibited exogenously GRP stimulated gastric acid output and plasma gastrin release dose dependently. Furthermore, BIM26226 markedly inhibited intragastric acidity and completely suppressed sham feeding stimulated acid output but had no effect on plasma gastrin in response to either food or sham feeding. Based on our data, we propose that GRP is a physiological regulator of gastric acid secretion. Gastrin release however does not seem to be a physiologically relevant GRP mediated effect.
Gastric acid secretion is regulated by a complex interaction of neural, paracrine, and endocrine signals from the brain and gastrointestinal tract. GRP has been associated with meal stimulated acid stimulation by gastrin release. Regulation of gastrin secretion includes stimulatory factors such as acetylcholine and local luminal factors, including protein digestion products and luminal acidity ${ }^{17}$ but also inhibitory pathways such as somatostatin. $^{5} 1819$

The main finding of our study was that acid secretion after oral liquid meal intake and sham feeding was markedly inhibited by GRP receptor blockade whereas plasma gastrin release remained unchanged. Several studies have shown that intravenous GRP/bombesin stimulate gastrin release and acid output in humans. ${ }^{4620}$ This effect however may be more of a pharmacological than physiological event. The dose dependent inhibition of GRP induced acid secretion in our study demonstrates the antagonistic activity of BIM26226 in humans which has previously been shown only in animals. ${ }^{910}$ The ability of BIM26226 to completely block acid output in response to modified sham feeding and to markedly suppress intragastric acidity after oral food indicates that endogenous GRP is involved in the regulation of postprandial acid production in humans. This action is not mediated by gastrin. The observation is further supported by the finding of an unchanged gastrin mRNA. Furthermore, somatostatin mRNA was not altered by the GRP receptor antagonist. The finding is at odds with the hypothesis that elevated somatostatin mRNA expression in the antrum mucosa (acting on G cells) or in the corpus (directly inhibiting the parietal cell) could have explained BIM26226 mediated inhibition of acid secretion.

Based on our findings, we tried to define the potential role of GRP in regulating gastric acid secretion. Stimulation of the vagus nerve induces acetylcholine release near parietal cells, histamine containing cells, and somatostatin producing D cells. ${ }^{21-23}$ Muscarinic receptors of the $M_{3}$ type have been identified on parietal cells ${ }^{24}$ but muscarinic receptors are probably also present on ECL cells and on D cells. Stimulation of acetylcholine release activates several stimulatory pathways of acid production, such as direct stimulation of the parietal cell and indirect stimulation of the parietal cell through stimulation of histamine release by enterochromaffin-like (ECL) cells. Histamine stimulates parietal cell acid production through activation of histamine receptors. ${ }^{25}$ Muscarinic receptors on D cells potentially inhibit somatostatin release thereby reducing the inhibitory effect of somatostatin on ECL and parietal cells. We suggest that GRP acts from an intramural ganglion within the $\mathrm{N}$ vagus to regulate acetylcholine release but this last statement requires experimental confirmation. Thus increased acetylcholine secretion results in direct stimulation of the parietal cell and in histamine release from ECL cells. As histamine and acetylcholine interact at the level of the parietal cell to stimulate acid 
secretion, interference with these two stimulatory pathways through endogenous blockade could induce a marked reduction in acid output. We believe that GRP is a regulator of acid production in humans but the hypothesis requires experimental support.

The physiological role of endogenous GRP in regulating gastrin secretion in humans remains unknown. Our results have clearly shown that GRP can regulate gastric acid secretion independent of gastrin release. Several aspects remain unclear. Firstly, GRP preferring bombesin receptors on human $G$ cells have not been investigated in detail. Secondly, bombesin and GRP enhanced gastrin release from cultured human $G$ cells but the action of a putative bombesin antagonist was difficult to assess. ${ }^{24}{ }^{26}$ Furthermore, species differences in animal models make it difficult to extrapolate findings of these studies to humans. As gastrin release is regulated by various other factors, including nutrient components, alteration in gastrin secretion with BIM26226 may be demonstrable under other experimental conditions.

In conclusion, we have demonstrated that BIM26226 is an effective GRP receptor antagonist with respect to inhibition of GRP stimulated gastrin release and acid production in humans. Furthermore, these studies have confirmed the usefulness of BIM2662 as a tool to investigate the physiological activity of endogenous GRP, suggesting a role for this neuropeptide in regulating acid secretion in humans.

We thank Carita Frei for editorial assistance and for preparation of the manuscript. The support of the Swiss National Science
Foundation (grant No 3200-40604.94/1) and Ipsen InterFoundation (grant No 3200-40604.94/1) and
national, London, UK, is gratefully acknowledged.

1 Price J, Penman E, Wass JA, et al. Bombesin-like immunoreactivity in human gastrointestinal tract. Regul immunoreactivity

2 Ferris HA, Carroll RE, Lorimer DL, et al. Location and characterization of the human GRP receptor expressed by gastrointestinal epithelial cells. Peptides 1997;18:663-72.

3 Walsh JH, Maxwell V, Ferrari J, et al. Bombesin stimulates human gastric function by gastrin-dependent and independent mechanisms. Peptides 1981;29(suppl 2):193-8.

4 Varner AA, Modlin IM, Walsh JH. High potency of bombesin for stimulation of human gastrin release and gastric acid secretion. Regul Pept 1981;1:289-96.

5 Chew CS. Peptidergic regulation of gastric acid secretion. In: Brown DR, ed. Gastrointestinal regulatory peptides. Berlin: Springer, 1993:199-252.
6 Knigge U, Holst JJ, Knuhtsen S, et al. Gastrin-releasing peptide: pharmacokinetics and effects on gastro-enteropancreatic hormones and gastric secretion in normal men. $\mathcal{f}$ Clin Endocrinol Metab 1984;59:310-15.

7 Hildebrand P, Werth B, Beglinger C, et al. Human gastrinreleasing peptide: biological potency in humans. Regul Pept 1991;36:423-33.

8 Jensen RT, Coy DH. Progress in the development of potent bombesin receptor antagonists. Trends Pharmacol Sci 1991; 12:13-19.

9 Dietrich JB, Hildebrand P, Baselgia Jeker L, et al. Effects of BIM26226, a potent and specific bombesin receptor antagonist, on amylase release and binding of bombesinlike peptides to AR4-2J cells. Regul Pept 1994;53:65-173.

10 Coy DH, Mungan Z, Rossowski WJ, et al. Development of a potent bombesin receptor antagonist with prolonged in vivo inhibitory activity on bombesin-stimulated amylase and protein release in the rat. Peptides 1992;13:775-81.

11 Varga G, Reidelberger RD, Liehr RM, et al. Effects of potent bombesin antagonist on exocrine pancreatic secretion in rats. Peptides 1991;12:493-7.

12 Feldman M, Richardson CT. Role of thought, sight, smell, and taste of food in the cephalic phase of gastric acid secretion in humans. Gastroenterology 1986;90:428-33.

13 Gibbons AH, Legon S, Walker MM, et al. The effect of gastrin-releasing peptide on gastrin and somatostatin messenger RNAs in humans infected with Helicobacter pylori. Gastroenterology 1997;112:1940-7.

14 Hydén S. A turbidimetric method for the determination of higher polyethylene glycols in biological materials. Kungl Lantbrukshögskolans Ann 1956;22:139-45.

15 Whitehouse I, Beglinger C, Rüttimann G, et al. Inhibition of pentagastrin-stimulated acid secretion after subcutaneous administration of a new somatostatin analogue. Gut 1986;27:141-6.

16 Sachs L. Angewandte Statistik. Berlin: Springer, 1984:552.

17 Taylor IL, Mannon P. Gastrointestinal hormones. In: Yamada T, Alpers DH, Owyang C, et al, eds. Textbook of gastroenterology, vol. 1. Philadelphia: Lippincott, 1991:2449.

18 Schubert ML, Jong MJ, Makhlouf GM. Bombesin/GRPstimulated somatostatin secretion is mediated by gastrin in the antrum and intrinsic neurons in the fundus. $A m$ f Physiol 1991;261:G885-9.

19 Schubert ML, Hightower J, Coy DH, et al. Regulation of acid secretion by bombesin/GRP neurons of the gastric fundus. Am F Physiol 1991;260:G156-60.

20 Sjövall M, Lindstedt G, Olbe L, et al. Effect of parietal cell vagotomy and cholinergic blockade on gastrin release in man induced by gastrin-releasing peptide. Digestion 1990; 46:114-20.

21 Feldman M. Inhibition of gastric acid secretion by selective and nonselective anticholinergics. Gastroenterology 1984;86: $361-6$.

22 Ekelund M, Håkanson R, Vallgren S. Effects of cimetidine, atropine and pirenzepine on basal and stimulated gastric acid secretion in the rat. Eur F Pharmacol 1987;138:225-32.

23 Yanagisawa K, Yang H, Walsh JH, et al. Role of acetylcholine, histamine and gastrin in the acid response to intracisternal injection of TRH analog, RX 77368, in the rat. Regul Pept 1990;27:161-70.

24 Pfeiffer A, Hanack C, Kopp R, et al. Human gastric mucosa expresses glandular M3 subtype of muscarinic receptors. Dig Dis Sci 1990;35:1468-72.

25 Soll AH. Gastric mucosal receptors. In: Schultz SG, Makhlouf GM, Rauner BB, eds. Handbook of physiology. Section 6: the gastrointestinal system, vol. II. Bethesda, MD: American Physiological Society, 1989:193-214.

26 Campos RV, Buchan AMJ, Meloche RM, et al. Gastrin secretion from human antral G-cells in culture. Gastroenterology 1990;99:36-44. 